\title{
PENERAPAN METODE DISCOVERY INKUIRI PADA PEMBELAJARAN SAINS ANAK USIA DINI
}

\author{
Diani Magasida \\ Pascasarjana Universitas Padjajaran Bandung \\ dianimagasida@gmail.com
}

Article received: 11 Maret 2017 Review process: 15 Maret 2017

Article published: 30 Maret 2017

\begin{abstract}
Abstrak
Belajar pada hakikatnya merupakan proses interaksi terhadap semua situasi yang ada di sekitar individu. Belajar dapat dipandang sebagai proses yang diarahkan kepada tujuan dan proses berbuat melalui berbagai pengalaman, belajar juga merupakan proses melihat, mengamati, dan memahami sesuatu. Anak usia dini tentunya mampu belajar dengan kondisi apapun dan dimanapun dia berada. Untuk mengoptimalkan perkembangannya, diperluka stimulasi melalui berbagai sistem pembelajaran yang dirancang sesuai dengan perkembangan anak. Tindakan yang dirancang untuk mendukung proses belajar anak, harus memperhitungkan hal-hal yang berperan terhadap tumbuh kembang anak. Metode pembelajaran dan media pembelajaran tentunya harus tepat dan memenuhi standar pembelajaran untuk anak usia dini. Saat ini masih banyak guru PAUD yang belum mampu menyampaikan pembelajaran sains dengan menerapkan metode pembelajaran yang dikemas secara inovatif dan berbeda, sehingga indikator capaian perkembangan anak belum tercapai secara maksimal. Untuk mengoptimalkan perkembangan anak usia dini, maka salah satu strategi yang dilakukan adalah melalui penerapan metode Discovery Inkuiri. Melalui penerapan metode discovery inquiri pada pembelajaran anak usia dini, diharpkan dapat memberikan rangsangan perkembangan kepada peserta didik sehingga aspek-aspek perkembangan dapat tercapai dengan maksimal.
\end{abstract}

\section{Kata Kunci: Metode discovery inquiri, Pembelajaran sains, Anak usia dini}

\section{A. PENDAHULUAN}

Sains pada dasarnya merupakan suatu proses ilmiah yang dapat terjadi setiap saat dan bahkan melekat dalam kehidupan sehari-hari. Sains menurut Amin (1987) didefinisikan sebagi bidang ilmu alamiah dengan ruang lingkup zat dan energi baik yang terdapat pada mahluk hidup maupun yang terdapat pada mahluk tak hidup, lebih banyak mendiskusikan tentang alam (natural science) seperti fisika, kimia dan biologi (Ali Nugraha, 2008: 3). Dari definisi tersebut, maka dapat dikatakan bahwa sians tidak saja berbicara mahluk hidup namun juga mahluk tak hidup seperti alam raya, bebatuan, tanah serta isinya. Betapa luasnya analisis tentang definisi sains, sehingga memunculkan pendapat berbeda yang mengatakan bahwa sains merupakan Ilmu 
pengetahuan alam yang terdiri dari physical sciences (ilmu-ilmu astronomi, kimia, geologi, minerologi dan fisika) dan life sciences (biologi, zoology dan fisiologi). Namaun lebih jauh dikatakan bahwa science is a combination of both process skills (how children learn) and content (what children learn) (dodge, colker dan heroman 2000).

Dari pernyataan tersebut, maka sebetulnya sains itu bukan sesuatu hal yang hanya saja timbul dari alam kemudian dilihat dan selesai, namun lebih jauh kepada proses keterampilan anak dalam melakukan sesuatu dan terlibat dalam kegiatan itu. Hal ini yang menjadi dasar mengapa orang tua semestinya terlibat dalam kegiatan permainan anak-anak, orang tua melibatkan anak dalam memilih permainan atau tema yang akan disampaikan, sehingga selain mampu mengarahkan dan memberikan pendampingan secara lebih baik, anak lebih termotifasi dan lebih kreatif dalam melakukan segala hal. Guerra (1992) berpendapat bahwa kondisi yang diperlukan dalam mendukung permainan agar memiliki kualitas yang bagus, maka diperlukan beberapa hal yaitu: (1) Mengaktifkan anak-anak untuk mengambil risiko sehingga anak menjadi kreatif dalam menemukan ide-ide mereka yang sangat lucu (2) Menyelenggarakan pengaturan fisik untuk memaksimalkan kesempatan belajar (3) Keterlibatan orang dewasa (4) Mengajak anak-anak untuk berbagi inisiatif tentang apa yang harus dipelajari (5) Mengembangkan sistem yang efektif dalam melakukan observasi dan pencatatan untuk menginformasikan perencanaan kurikulum yang akan dilakukan (Dan Davies, 2011: 35).

Pada dasarnya banyak peristiwa yang terjadi disekeliling kita yang merupakan gejala sains, misalnya peristiwa jatuhnya biji-bijian ke tanah, peristiwa tumbuhnya biji-bijian secara alami, air mengalir dari dataran tinggi ke dataran rendah, peristiwa hujan, embun di pagi hari, cuaca dingin, cuaca panas serta banyak lagi hal-hal lainnya yang merupakan gejala sains. Peristiwa-peristiwa sederhana inilah yang merupakan sains yang sangat melekat dengan kehidupan kita sehari-hari, sehingga dapat dijadikan referensi pembelajaran bagi siapapun, terutama pembelajaran dan pengenalan bagi anak usia dini. Disinilah pentingnya guru pendamping dan orang tua dalam mengembangkan sains bagi anak usia dini secara nyata. Hal utama yang dilakukan oleh guru dalam pengembangan sains anak usia dini adalah berfokus pada pengembangan keterampilan proses seperti mengamati, membandingkan, mengukur, mengklasifikasi, mengkomunikasi, menginferensi, membuat model, memprediksi, menyelidiki, menarik kesimpulan dan sebagainya.

A good science program is skillfully integrated into the total life of the classroom (Copple \& Bredekamp, 2009). Dari pernyataan tersebut, maka program pembelajaran sains 
untuk anak usia dini harus terintegrasi dengan kehidupan anak secara nyata. Gejala-gejala alam atau peristiwa-peristiwa alam yang dialami oleh anak-anak dikuatkan dalam pembelajaran di dalam kelas, sehingga sains sangat melekat dengan kehidupan anak sehari-hari. Selain itu sains yang diajarkan pada anak usia dini disesuaikan dengan tingkat perkembangan anak tersebut, sehingga tentunya berbeda perlakuan antara usia yang satu dengan usia lainnya.

\section{B. KAJIAN TEORETIK}

\section{a. Perkembangan Sains Anak Usia Dini}

Secara garis besar tingkat pencapaian perkembangan kelompok usia 5-6 tahun dalam lingkup perkembangan kognitif (pengetahuan umum dan sains) adalah sebagai berikut:

\section{Tabel 1 Tingkat Pencapaian Perkembangan Kognitif}

\begin{tabular}{|c|c|c|}
\hline $\mathbf{N}$ & $\begin{array}{c}\text { Lingkup } \\
\text { Perkembangan }\end{array}$ & Usia 5 - 6 Tahun \\
\hline \multirow[t]{6}{*}{ A } & \multirow{6}{*}{$\begin{array}{l}\text { Pengetahuan Umum } \\
\text { dan sains }\end{array}$} & Mengklasifikasi benda berdasarkan fungsi \\
\hline & & $\begin{array}{l}\text { Menunjukan aktifitas yang bersifat explorative dan } \\
\text { menyelidik (seperti yang terjadi ketika air ditumpahkan) }\end{array}$ \\
\hline & & Menyusun perencanaan kegiatan apa yang akan dilakukan \\
\hline & & $\begin{array}{l}\text { Mengenal sebab akibat tentang lingkungannya (angina bertiup } \\
\text { menyebabkan daun bergerak, air dapat menyebabkan sesuatu } \\
\text { menjadi basah }\end{array}$ \\
\hline & & $\begin{array}{l}\text { Menunjukan inisiatif dalam memilih tema permaiann (seperti: } \\
\text { ayo kita bermain pura-pura seperti burung) }\end{array}$ \\
\hline & & Memecahkan masalah sederhana dalam kehidupan sehari-hari \\
\hline \multirow[t]{5}{*}{ B } & \multirow{5}{*}{$\begin{array}{l}\text { Konsep bentuk, } \\
\text { warna dan pola }\end{array}$} & Mengenal perbedaan berasarkan ukuran \\
\hline & & $\begin{array}{l}\text { Mengklasifikasikan benda berdasarkan warna bentuk dan } \\
\text { ukuran }\end{array}$ \\
\hline & & $\begin{array}{l}\text { Mengklasifikasikan benda yang lebih banyak ke dalam } \\
\text { kelompok yang sama atau kelompok yang sejenis atau } \\
\text { kelompok berpasangan yang lebih dari dua variasi }\end{array}$ \\
\hline & & Mengenal pola $\mathrm{ABCD}-\mathrm{ABCD}$ \\
\hline & & $\begin{array}{l}\text { Mengurutkan benda berdasarkan ukuran dari paling kecila } \\
\text { atau paling besar atau sebaliknya }\end{array}$ \\
\hline
\end{tabular}




\begin{tabular}{|c|c|c|}
\hline $\mathrm{C}$ & $\begin{array}{c}\text { Konsep bilangan, } \\
\text { lambing bilangan dan } \\
\text { huruf }\end{array}$ & Menyebutkan lambang bilangan 1-10 \\
\cline { 3 - 3 } & Mencocokan bilangan dengan lambing bilangan \\
\cline { 2 - 3 } & & Mengenal berbagai macam lambing huruf vocal dan konsonan \\
\hline
\end{tabular}

Pengembangan sains bagi anak usia dini merupakan suatu hal yang sangat penting sehingga perlu dikenalkan kepada anak sedini mungkin. Hal ini sesuai dengan tujuan pembelajaran sains yaitu sebagai alat untuk menguasai alam dan untuk memberikan sumbangan bagi kesejahteraan manusia. Hal ini merupakan alasan yang sangat mendasar sehingga melalui penguasaan sains, manusia akan semakin sejahtera, bersahabat dengan alam, mampu melindungi alam serta mengetahui gejala-gejala alam yang membahayakan kehidupan mahluknya. Beberapa upaya yang dapat dilakukan dalam mengoptimalisasikan pengembangan pembelajaran sain bagi anak usia dini diantaranya adalah (1) kurikulum pengembangan sians bagi anak usia dini hendaklah dikembangkan terintegrasi yaitu dapat menyajikan aktifitas belajar sians secara terpadu yang dikemas melalui tema, proyek dan bermain (2) dilakukan upaya terus menerus untuk meningkatkan mutu pengajar yang terlibat langsung dalam pembelajaran sians anak usia dini (3) meningkatkan peran dan keterlibatan mayarakat dalam pembelajaran, sehingga masyarakat dapat terlibat dalam system pendidikan yang nyata dan terlibat langsung dalam pembelajaran.

Melalui upaya-upaya tersebut, maka secara tidak langsung anak akan terlihat minimal dari tiga aspek yaitu cara kerja dalam menyingkap alam dan menyelesaikan permasalahan, dari kemampuan menjelaskan hasil dan cara memperolehnya serta dari sikap terhadap alam dan permasalahan yang dihadapinya. Inilah yang dinamakan bahwa suatu saat anak akan menjadi seorang saintis yang memiliki sikap-sikap sebagi seorang saintis. Untuk mengetahui bahwa anak memiliki sikap saintis, maka dapat diidentifikasi dari beberapa hal berikut (1) memiliki hasrat ingin tahu yang sangat tinggi (2) memiliki sikap tidak mudah putus asa (3) memiliki sikap keterbukaan untuk dikritik dan diuji (4) memiliki sikap menghargai dan enerima masukan (5) memiliki sikap jujur (6) memiliki sikap kritis (7) memiliki sikap kreatif (8) memiliki sikap positif terhadap kegagalan (9) memiliki sikap rendah hati (10) hanya menyimpulkan bila didukung dengan data dan fakat yang ada (Ali Nugraha, 2009: 10).

Dari semua sikap yang diungkapkan diatas maka bagaimanakah sesungguhnya kedudukan sains ditinjau dari sudut anak. Hal ini diungkapkan oleh Carson 1965 (Holt, 1991) yang megungkapkan bahwa sains bagi anak-anak adalah segala sesuatu yang menakjubkan, 
sesuatu yang ditemukan dan dianggap menarik serta memberi pengetahuan atau merangsangnya untuk mengetahui dan menyelidikinya. Sebagai contoh bahwa anak-anak yang melakukan kegiatan mengejar-ngejar capung di sawah kemudian menangkapnya dan kemudian dilepaskan ulang, atau anak-anak yang bermain laying-layang di lapangan terbuka. Dari kegiatan ini anakanak akan belajar bereksperimen sendiri terhadap apa yang ia lakukan, sehingga agar capung tidak terlalu jauh terbangnya, maka salah satu kakinya diputuskan misalnya. Atau laying-layang agar tidak menyangkut di pohon, maka yang dilakukan adalah tidak menerbangkan layangan di wilayah dengan pepohonan yang lebat. Ini merupakan contoh kecil dari kegiatan yang anak lakukan, sehingga sebetulnya apapun yang dilakukan anak-anak memberikan pengetahuan baru dan pengalaman melakukan sesuatu, sehingga proses berfikir kritis, mencintai sesuatu, menyayangi satu binatang dan megetahui sesuatu tentang gejala alam, secara langsung akan terjadi pada diri anak. Kemudian agar anak memiliki kecintaan dan menyayangi alam, maka harus dikembangkan melalui pembelajaran sains. Anak-anak diberikan rangsangan dalam kegiatan ilmu pengetahuan alam melalui hal-hal yang sangat praktis namun tentunya menyentuh terhadap perkembangan berfikir anak. Hal inilah yang harus difahami oleh pendidik, sehingga pendidik memiliki rancangan bagaimana memberikan pengajaran kepada anak tentang sains sesuai dengan tujuan yang hendak dicapai.

Menurut Leeper (1994) terdapat empat hal yang merupakan tujuan dari pengembangan pembelajaran sains anak usia dini yaitu (1) pembelajaran sains anak usia dini ditujukan agar anak-anak memiliki kemampuan memecahkan masalah yang dihadapi melalui penggunaan metode sains, sehingga anak-anak terbantu dan menjadi terampil dalam menyelesaikan berbagai hal yang dihadapinya (2) agar anak-anak memiliki sikap ilmiah (3) agar anak-anak mendapatkan pengetahuan dan informasi ilmiah yang lebih dipercaya dan berdasarkan pada standar keilmuan yang semestinya (4) agar anak-anak menjadi lebih berminat dan tertarik untuk menghayati sains yang berada dan ditemukan di lingkungan dan alam sekitarnya. Apabila hal-hal yang terkait dengan sains terus menerus dibelajarkan oleh pendidik, maka hal ini akan menjadi fondasi yang sangat baik, sehingga kemampuan seorang saintis akan terus terasah.

\section{PEMBAHASAN}

\section{Pembelajaran Sains dengan Metode Discovery Inkuiri}


Metode langkah operasional dari strategi pembelajaran yang dipilih dalam mencapai tujuan belajar, sehingga sumber belajar dalam menggunakan suatu metode pembelajaran harus disesuaikan dengan jenis strategi yang digunakan (Ihat Hatimah, 2003: 9). Metode diartikan sebagai kerangka konseptual yang digunakan sebagai pedoman dalam melakukan kegiatan. Metode pembelajaran berarti cara-cara yang dipakai untuk menyajikan bahan pelajaran kepada peserta didik untuk mencapai tujuan pembelajaran yang telah ditentukan. Salah satu keterampilan guru yang memegang posisi penting adalah keterampilan memilih metode pembelajaran. Pemilihan metode pembelajaran berkaitan langsung dengan usaha guru dalam menampilkan pengajaran sesuai dengan situasi dan kondisi, sehingga tujuan pembelajaran dapat tercapai secara optimal. Banyak metode pembelajaran yang dapat dipergunakan dalam pembelajaran, salah satu diantaranya adalah metode inkuiri discovery. Inkuiri discovery sebenarnya dua metode, akan tetapi dalam penggunaanya selalu bertalian erat dan selalu depergunakan bersama-sama.

Untuk memperjelas metode tersebut, maka inkuri berasal dari Inggris "inquiri" yang secara harfiah berarti penyelidikan. Metode inkuiri merupakan metode yang mempersiapkan peserta didik pada situasi untuk melakukan eksperimen sendiri secara luas agar melihat apa yang terjadi, ingin melakukan sesuatu, mengajukan pertanyaan-pertanyaan, dan mencari jawaban sendiri, serta menghubungkan serta membandingakan apa yang peserta didik temukan dengan penemuan lain. Dalam metode inkuiri peserta didik didorong untuk belajar melalui keterlibatan aktif dan mengadakan suatu penelitian (percobaan) untuk menemukan suatu penemuan tertentu. Melalui inkuiri memacu peserta didik untuk mengetahui serta memotivasi peserta didik untuk memecahkan masalah secara mandiri dan memiliki keterampilan kritis dalam menganilis informasi.

Inkuiri memberikan kepada peserta didik pengalaman-pengalaman belajar yang nyata dan aktif. Peserta didik dilatih bagaimana cara memecahkan masalah, membuat keputusan, dan memperoleh keterampilan. Inkuiri dalam bahasa Inggris inquiry, berarti pertanyaan, atau pemeriksaan, penyelidikan. Sasaran utama kegiatan pembelajaran inkuiri adalah (1) keterlibatan siswa secara maksimal dalam proses kegiatan belajar (2) keterarahan kegiatan secara logis dan sistematis pada tujuan pembelajaran (3) mengembangkan sikap percaya pada diri siswa tentang apa yang ditemukan dalam proses inkuiri. Peranan guru dalam pembelajaran inkuiri adalah sebagai (1) motivator, memberi rangsangan agar siswa aktif dan bergairah berpikir (2) fasilitator, menunjukkan jalan keluar jika siwa mengalami kesulitan (3) penanya, menyadarkan siswa dari 
kekeliruan yang mereka buat (4) administrator, bertanggung jawab terhadap seluruh kegiatan kelas (5) pengarah, memimpin kegiatan siswa untuk mencapai tujuan yang diharapkan (6) manajer, mengelola sumber belajar, waktu, dan organisasi kelas; (7) rewarder, memberi penghargaan pada prestasi yang dicapai siswa (Nurhadi dkk, 2004: 135).

Gulo (Trianto: 2009: 168) menyatakan, bahwa kemampuan yang diperlukan untuk melaksanakan pembelajaran inkuiri adalah sebagai berikut:

1) Mengajukan pertanyaan atau permasalahan, Kegiatan inkuiri dimulai ketika pertanyaan atau permasalahan diajukan. Untuk meyakinkan pertanyaan sudah jelas, pertanyaan tersebut dituliskan di papan tulis, kemudian siswa diminta untuk merumuskan hipotesis.

2) Merumuskan hipotesis, Hipotesis adalah jawaban sementara atas pertanyaan atau solusi permasalahan yang dapat diuji dengan data. Untuk memudahkan proses ini, guru menanyakan kepada siswa gagasan mengenai hipotesis yang mungkin. Dari semua gagasan yang ada, dipilih salah satu hipotesis yang relevan dengan permasalahan yang diberikan.

3) Mengumpulkan data, Hipotesis digunakan untuk menuntun proses pengumpulan data. Data yang dihasilkan dapat berupa table, matrik, atau grafik.

4) Analisis data, Siswa bertanggung jawab menguji hipotesis yang telah dirumuskan dengan menganalisis data yang telah diperoleh.

5) Membuat kesimpulan, Langkah penutup dari pembelajaran inkuiri adalah membuat kesimpulan sementara berdasarkan data yang diperoleh siswa.

Adapun tahapan pembelajaran inkuiri menurut Eggen \& Kauchak sebagai berikut:

\section{Tabel 2 Tahapan Pembelajaran Inkuiri}

\begin{tabular}{|l|l|}
\hline \multicolumn{1}{|c|}{ Fase } & \multicolumn{1}{c|}{ Prilaku Guru } \\
\hline atau masalah & $\begin{array}{l}\text { Guru membimbing siswa mengidentifikasi masalah dan masalah } \\
\text { dituliskan di papan tulis. Guru membagi siswa dalam kelompok. }\end{array}$ \\
\hline Membuat hipotesis & $\begin{array}{l}\text { Guru memberikan kesempatan pada siswa untuk curah pendapat } \\
\text { dalam membentuk hipotesis. } \\
\text { Guru membimbing siswa dalam menentukan hipotesis yang } \\
\text { releven dengan permasalahan dan memprioritaskan hipotesis mana } \\
\text { yang menjadi prioritas penyelidikan. }\end{array}$ \\
\hline Merancang percobaan & $\begin{array}{l}\text { Guru memberikan kesempatan pada siswa untuk menentukan } \\
\text { langkah-langkah yang sesuai dengan hipotesis yang akan }\end{array}$ \\
\hline
\end{tabular}




\begin{tabular}{|c|c|}
\hline & $\begin{array}{l}\text { dilakukan. Guru membimbing siswa mengurutkan langkah- } \\
\text { langkah percobaan. }\end{array}$ \\
\hline $\begin{array}{l}\text { Melakukan percobaan } \\
\text { untuk memperoleh } \\
\text { informasi }\end{array}$ & $\begin{array}{l}\text { Guru membimbing siswa mendapatkan informasi melalui } \\
\text { percobaan. }\end{array}$ \\
\hline $\begin{array}{l}\text { Mengumpulkan dan } \\
\text { menganalisis data }\end{array}$ & $\begin{array}{l}\text { Guru memberi kesempatan pada tiap kelompok untuk } \\
\text { menyampaikan hasil pengolahan data yang terkumpul }\end{array}$ \\
\hline
\end{tabular}

Sementara itu metode discovery adalah metode penemuan, merupakan metode yang lebih menekankan pada pengalaman langsung. Pembalajaran dengan metode discovery lebih mengutamakan proses dari pada hasil belajar. Ada beberapa langkah dalam metode discovery yaitu (1) Adanya masalah yang akan dipecahkan, (2) Sesuai dengan tingkat perkembangan kognitif peserta didik, (3) Konsep atau prinsip yang harus ditemukan oleh peserta didik melalui kegiatan tersebut perlu dikemukakan dan ditulis secara jelas, (4) Harus tersedia alat dan bahan yang diperlukan, (5) Susunan kelas diatur sedemikian rupa sehingga memudahkan terlibatnya arusbebas pikiran peserta didik dalam proses pembelajaran, (6) Guru harus memberikan kesempatan kepada peserta didik untuk mengumpulkan data, (7) Guru harus memberikan jawaban dengan cepat dan tepat dengan data dan informasi yang diperlukan peserta didik( E. Mulyasa: 110).

Pendekatan Discovery merupakan pendekatan mengajar yang memerlukan proses mental, seperti mengamati, mengukur, menggolongkan, menduga, men-jelaskan, dan mengambil kesimpulan. Pada kegiatan discovery guru hanya memberikan masalah dan siswa disuruh memecahkan masalah melalui percobaan. Pada pendekatan inquiry, siswa mengajukan masalah sendiri sesuai dengan pengarahan guru. Keterampilan mental yang dituntut lebih tinggi dari discovery antara lain: merancang dan melakukan percobaan, mengumpulkan dan menganalisis data, dan mengambil kesimpulan. Beberapa kelebihan metode discovery yaitu (1) Dalam penyampaian bahan, metode discovery menggunakan kegiatan dan pengalaman langsung dan kongkrit. Kegiatan dan pengalaman demikian lebih menarik perhatian peserta didik, dan memungkinkan pembentukan konsep konsep abstrak yang mempunyai makna, (2) Metode belajar discovery lebih realistis dan punya makna, sebab peserta didik bekerja langsung dengan contoh-contoh nyata. Peserta didik langsung mengaplikasikan kemampuannya, (3) Metode 
belajar discovery merupakan suatu model belajar pemecahan masalah. Para peserta didik belajar langsung menerapkan prinsip-prinsip dan langkah-langkah pemecahan masalah, (4) Transfer tidak dinantikan sampai kegiatan lain, tetapi langsung dilakukan, sebab metode discovery berisi sejumlah transfer, (5) Metode discovery banyak memberikan kesempatan bagi keterlibatkan peserta didik dalam proses pembelajaran, kegiatan demikian akan banyak membangkitkan motivasi belajar, sebab proses pembelajaran akan disesuaikan dengan minat dan kebutuhan peserta didik.

Dari kedua metode pembelajaran yang telah disampaikan diatas, maka metode discovery inkuiri pada dasarnya dua metode pembelajaran yang saling berkaitan satu dengan yang lain. Inkuiri artinya penelitian, sedangkan discovery adalah penemuan. Dengan melalui penelitian peserta didik akhirnya dapat memperoleh suatu penemuan.

\section{Langkah-langkah dalam metode Discovery Inkuiri}

Langkah-langkah metode inkuiri dan discovery dinilai cukup ilmiah dalam melakukan penyelidikan dalam rangka memperoleh suatu penemuan. Mulai dari merumuskan masalah, hipotesis, mengumpulkan data, menguji hipotesis dengan data dan menarik kesimpulan sangat membimbing peserta didik untuk berfikir obyektif dalam memecahkan masalah. Jadi dengan metode inkuiri discovery, peserta didik melakukan suatu proses mental yang bernilai tinggi (Asra Sumiati, 2009: 103).

Dalam pembelajaran inkuiri discovery ini peserta didik menjadi lebih aktif belajar. Tujuan utama metode inkuiri discovery adalah mengembangkan keterampilan intelektual, berfikir kritis, dan mampu memecahkan masalah secara ilmiah. Penekanan utama pembelajaran dengan metode inkuiri discovery adalah (1) Pengembangan kemampuan berfikir individual lewat penelitian, (2) Peningkatan kemampuan mempraktekkan metode dan teknik penelitian, (3) Latihan keterampilan intelektual khusus, yang sesuai dengan cabang ilmu tertentu, dan (4) latihan menemukan sesuatu, seperti belajar bagaimana belajar. Peranan guru yang penting adalah (1) Menciptakan suasana bebas berfikir sehingga peserta didik berani bereksplorasi dalam penemuan dan pemecahan masalah, (2) Fasilitator dalam pembelajaran, (3) Rekan diskusi dalam klasifikasi dan pencarian alternatif pemecahan masalah, (4) Pembimbing pembelajaran, pendorong keberanian berfikir alternatif dalam pemecahan masalah. Peran peserta didik yang penting adalah (1) Mengambil prakarsa dalam pencarian masalah dan pemecahan masalah, (2) Pelaku aktif dalam pembelajaran, (3) Penjelajah tentang masalah dan metode pemecahan 
masalah, dan (4) Penemu pemecahan masalah. Evaluasi pembelajaran metode inkuiri discovery adalah (1) Keterampilan. pencarian dan perumusan masalah, (2) Keterampilan pengumpulan data atau informasi, (3) Keterampilan meneliti tentang objek, seperti benda, sifat benda, kondisi, atau peristiwa dan pelaku, (4) Keterampilan menarik kesimpulan, dan (5) Membuat laporan (Dimyati dan Mudjiono, 2006: 173).

Belajar metode inkuiri discovery merupakan suatu kegiatan belajar yang mengutamakan aktifitas peserta didik. Inkuiri menekankan pada proses mencari atau penelitiannya, sedangkan discovery menekankan pada penemuannya. Jika seseorang menggunakan metode pencarian (berinkuiri), kemungkinan besar akan menemukan, dan suatu penemuan (discovery) adalah hasil dari suatu pencarian. Olah karena itu keduanya mempunyai makna yang sama. Langkah-langkah umum metode inkuiri discovery adalah (1) Identifikasi kebutuhan peserta didik, (2) Seleksi pendahuluan terhadap prinsip- prinsip pengertian dan konsep yang akan dipelajari, (3) Seleksi materi pembelajaran dan problema atau tugas-tugas, (4) Membantu memperjelas tugas yang akan dipelajari sesuai peranan masing-masing peserta didik, (5) Mempersiapkan setting kelas dan alatalat yang akan dipelajari,(6) Memberi kesempatan kepada peserta didik untuk melakukan penemuan,(7) Membantu peserta didik dengan informasi atau data jika diperlukan,(8) Memimpin analisis sendiri (self analysis) dengan pertanyaan yang mengarahkan dan mengidentifikasi proses, (9) Merangsang terjadinya interaksi antar peserta didik,(10) Membantu peserta didik merumuskan prinsip prinsip dan generalisasi atas hasil penemuan.

\section{PENUTUP}

Anak Usia dini merupakan tahapan yang sangat mendasar bagi perkembangan individu tersebut (the golden age). Berbagai upaya strategis akan diambil sehingga anak mencapai perkembangan yang optimal. Guru PAUD tentunya sebagai orang yang paling mengetahui perkembangan anak, sehingga berbagai strategi dan metode pembelajarn selalu dicoba dan diterapkan. Kesusksesan anak merupakan kesuksesan bagi seorang pendidik, begitupun sebaliknya jika mengalami kegagalan dalam membina, mengajar anak, pengasuhan, prilaku dan mendidiknya merupakan bencana bagi kehidupan anak dimasa yang akan dating.

Salah satu upaya strategi dalam peningkatan kemampuan anak didahului dengan pengenalan karakteristik dan tujuan pembelajaran yang akan diterapkan termasuk dalam bidang penerapan sains. Tujuan pembelajaran sains sejalan dengan kurikulum yang ada disekolah yaitu mengembangkan anak secara utuh baik pikiran, hati dan jasmaninya. Mengembangkan 
intelektual, emosional fisik jasmani maupun fisik kognitif, psikomotorik, afektif (Abruscato, 1982).

Dalam pengenalan pembelajaran sains bagi anak usia dini dapat ditempuh dengan berbagai metode yakni dengan menggunakan metode Inquiry Discovery. Metode ini sangat baik digunakan pada anak pra sekolah saat ini, terutama pada anak usia 4-6 ahun (TK/RA). Dalam mengembangkan metode inkuiri di kelas guru mempunyai peranan sebagai konselor, konsultan, teman yang kritis dan fasilitator. Ia harus dapat membimbing dan merefleksikan pengalaman kelompok, serta memberi kemudahan bagi kerja kelompok peserta didiknya. Ssementara itu strategi belajar discovery paling baik dilaksanakan dalam kelompok belajar kecil. Namun dapat juga dilakukan dalam kelompok belajar yang lebih besar. Meskipun tidak semua anak dapat terlibat dalam proses discovery, namun pendekatan ini dapat memberikan manfaat bagi anak yang belajar.

\section{DAFTAR PUSTAKA}

Davies, Dan. 2011. Teaching Science Creatively (Learning to Teach in The Primary School Series). London: Routledge.

Dimyati dan Mudjiono. 2006. Belajar dan Pembelajaran. Jakarta: Rineka Cipta.

Hatimah, Ihat. 2003. Strategi dan Metode Pembelajaran. Bandung: CV. Adira.

Jackman, Hilda. L. 2009. Early Education Curriculum (Child's Connection to the World) Fifth Edition. United States of America: Wadsworth Cengage Learning.

Mulyasa, H.E. 2007. Menjai Guru Profesional. Bandung: Rosda.

Nurhadi dkk. 2004. Pembelajaran Kontekstual dan Penerapan dalam KBK. Malang: UM Press.

Nugraha, Ali. 2008. Pengembangan Pembelajaran Sains Pada Anak Usia Dini. Bandung: JILSI Foundation.

2003. Pendidikan dan Latihan Profesi Guru Taman Kanak-Kanak. Jakarta: Pusat Pengembangan Profesi Pendidik BPSDMPK-PMP Kementerian Pendidikan dan Kebudayaan.

Trianto. 2007. Mendesain Pembelajaran Kontekstual (Contextual Teaching and Learning) di Kelas. Surabaya: Cerdas Pustaka Publisher.

Trianto. 2009. Mendesain Model Pembelajaran Inovatif Progresif. Jakarta: Kencana.

Sukmadinata, Nana Syaodah. 2005. Metode Penelitian Pendidikan. Bandung: Rosda Karya Remaja.

Sumiati, Asra. 2009. Metode Pembelajaran. Bandung: Wacana Prima. 
Siregar, Eveline dan Hartini Nara. 2011. Teori belajar dan pembelajaran. Bogor: Ghalia Indonesia. 